\title{
An Economic Analysis of Resource Use Efficiency, Technical Efficiency and Risk Management Strategies under Different Irrigation Methods in Tamil Nadu, India
}

\author{
K. Jayapradha*, J. S. Amarnath and B. Sivasankari \\ Department of Agricultural Economics, Tamil Nadu Agricultural University, Agricultural \\ College and Research Institute, Madurai, TN, India \\ *Corresponding author
}

\begin{abstract}
A B S T R A C T
Water is an important determinant factor of production of any crops in agriculture sector. Intensive and extensive cultivation of land depend mainly on the availability of water for irrigation. The various methods of irrigation are Flood, Furrow and Drip irrigation. The efficiency and risk of these irrigation methods is pivotal for agricultural development and any other new agricultural improvement of any region. So, this study concentrates on the economic efficiency and risk management strategies in flood, furrow and drip irrigation methods in Namakkal district of Tamil Nadu. Percentage analysis, Cobb-Douglas production function and Data Envelopment Analysis (DEA) were the analytical tools used to evaluate the objectives. The results revealed that economic performance for tapioca cultivation in drip irrigation was higher than the cotton cultivation in furrow irrigation and paddy cultivation in flood irrigation methods in terms of productivity and cost and returns. The net income for the tapioca cultivation was high over the cotton cultivation by 99.27 per cent and 117.37 per cent for the paddy cultivation. The results of resource use efficiency showed that manures and fertilizer cost, irrigation cost and plant production cost were significant in production of all the three crops. Economic efficiency in all the three irrigation methods showed that the irrigation resource was used at sub-optimal level and over utilization of seed and plant protection cost in flood and furrow methods respectively. Technical efficiency showed that all the paddy, cotton and tapioca crops in their respective irrigation methods was technically efficient since the mean level of technical efficiency is 95 per cent, 90 per cent and 91 per cent respectively. Scale efficiency indicated that all the paddy, cotton and tapioca crops in their respective irrigation methods operating at optimal size since the mean scale efficiency is more than 90 per cent for all the three crops. In case of risk management strategies, soil conservation and land management practices were ranked first in flood and furrow irrigation methods and effective irrigation management practices were ranked first in drip irrigation method.
\end{abstract}

\section{Introduction}

Water is an important determinant factor of production of any crops in agriculture sector.
Intensive and extensive cultivation of land depend mainly on the availability of water for irrigation. On average, agriculture accounts for 70 per cent of global freshwater 
withdrawals. Out of total irrigated area in world, China and India ranks first and second place respectively and which contributes more than one third of the total irrigated land globally. India has four per cent of world's fresh water. Out of which, 80 per cent is used in agriculture. In India, the irrigated area consists of about 36 per cent of the net sown area and the agricultural sector accounts for about 85 per cent of all water uses.

The irrigation efficiency of conventional irrigation method is 25 to 30 per cent because 70 to 75 per cent of water goes waste due to leaching and evaporation losses. One way to address these concerns is to utilize modern irrigation technology with high water application efficiency namely drip irrigation. So, this study involves the economic analysis of efficiency and risk management strategies under flood, furrow and drip irrigation methods in Namakkal district of Tamil Nadu.

The main objectives of this study include to study the economic performance in flood, furrow and drip irrigation methods. To study the resource use efficiency and economic efficiency of selected major crops in flood, furrow and drip irrigation methods. To study the technical efficiency of selected crops in flood, furrow and drip irrigation methods. To study the risk management strategies followed by farmers in flood, furrow and drip irrigation methods.

\section{Materials and Methods}

\section{Sampling design}

Namakkal district was purposively selected for the present study in the first stage. In the second stage, among the blocks in Namakkal district, Erumapatty block, Sendamangalam block, and Elachipalayam block were purposively selected for flood, furrow and drip irrigation methods respectively based on water availability for crop irrigation and cropping pattern.

Six villages were randomly selected in each block and the total numbers of villages selected were 18. From every selected village, 10 farmers were selected at random and that the total sample size was 180. Thus, each irrigation method has 60 sample farmers and multistage random sampling procedure was adopted for the study.

\section{Cobb-Douglas production function}

The form of regression model used in different irrigation methods for the respective crop was

$\mathrm{Y}=\mathrm{a} \mathrm{X}_{1}{ }^{\mathrm{b} 1} \mathrm{X}_{2}{ }^{\mathrm{b} 2} \mathrm{X}_{3}{ }^{\mathrm{b} 3} \mathrm{X}_{4}{ }^{\mathrm{b} 4} \mathrm{X}_{5}^{\mathrm{b} 5} \mathrm{X}_{6}^{\mathrm{b} 6} \mathrm{U}_{\mathrm{t}}$

Where,

$\begin{array}{ll}\mathrm{Y}= & \text { Yield (Rs/ha) } \\ \mathrm{X}_{1}= & \text { Seed cost (Rs/ha) } \\ \mathrm{X}_{2}= & \text { Manures and fertilizers cost } \\ (\mathrm{Rs} / \mathrm{ha}) & \\ \mathrm{X}_{3}= & \text { Irrigation cost (Rs/ha) } \\ \mathrm{X}_{4}= & \text { Plant protection cost (Rs/ha) } \\ \mathrm{X}_{5}= & \text { Human labour cost (Rs/ha) } \\ \mathrm{X}_{6}= & \text { Machine power cost (Rs/ha) } \\ \mathrm{U}_{\mathrm{t}}= & \text { Error term } \\ \mathrm{a}= & \text { Intercept } \\ \mathrm{b}_{1}, \mathrm{~b}_{2} . . \mathrm{b}_{6}= & \text { Regression co-efficient to be } \\ \text { estimated. } & \end{array}$

\section{Economic efficiency}

The economic efficiency of resource use and the Marginal Value products of each input were compared with its MIC in order to estimate the efficiency. Equality of $\mathrm{MVP}_{\mathrm{j}}$ to the MIC of input ' $\mathrm{j}$ ' indicates the optimum resource use of a particular input. Ratio of $\mathrm{MVP}_{\mathrm{j}}$ to the MIC of input ' $\mathrm{j}$ ' indicated the degree of resource use efficiency. 


\section{Data envelopment analysis}

The DEA was applied by using input orientation, in which one seeks input minimization to obtain a particular product level.

Under the assumptions of constant return to scale, the flowing linear programming model for measuring the efficiency of crop farms are

$\operatorname{Min}_{\theta, \lambda} \theta$

Subject to $-\mathrm{y}_{\mathrm{i}}+\mathrm{Y} \lambda \geq 0$

$\theta \mathrm{x}_{\mathrm{i}}-\mathrm{X} \lambda \geq 0$

$\lambda \geq 0$

Where,

$\mathrm{y}_{\mathrm{i}}$ is a vector $(\mathrm{m} \times 1)$ of output of the $\mathrm{i}^{\text {th }}$ Crop Producing Farms,

$\mathrm{X}_{\mathrm{i}}$ is vector $(\mathrm{k} \times 1)$ of inputs of the $\mathrm{i}^{\text {th }}$ Crop Producing Farms,

$\mathrm{Y}$ is a output matrix $(\mathrm{n} \times \mathrm{m})$ for $\mathrm{n}$ Crop Producing Farms,

$\mathrm{X}$ is the input matrix ( $\mathrm{n} \mathrm{x}$ ) Crop Producing Farms,

$\theta$ is the efficiency score, a scalar whose value will be the efficiency measure for the $i^{\text {th }}$ crop producing farms.

If $\theta=1$, crop producing farms will be efficient; otherwise, it will be inefficient, and

$\lambda$ is a vector ( $\mathrm{n} \times 1$ ) whose values are calculated to obtain the optimum solution.

\section{Results and Discussion}

Economic performance of flood, furrow and drip irrigation method

\section{Average Productivity of major crops}

The measure of productivity is defined as total output per unit area for each main crop and worked out separately in the flood, furrow and drip irrigation methods. The average productivity of major crops in farms under the three different irrigation methods is furnished in table 1 .

It could be seen from the table that the productivity of paddy was $6.70 \mathrm{t} / \mathrm{ha}$ and it was the crop only cultivated in flood irrigation method due to high requirement of water. Basavaraja et al., (2008) revealed that the technological change in paddy production has brought about 33.72 per cent productivity difference between the system of rice intensification method and traditional method of paddy. The productivity of sorghum was high in the furrow irrigation method with 3.10 t/ha followed by flood irrigation method with $2.50 \mathrm{t} / \mathrm{ha}$. With regard to the groundnut productivity, the drip irrigation method was higher with $2.71 \mathrm{t} / \mathrm{ha}$ followed by the flood irrigation method with $2.60 \mathrm{t} / \mathrm{ha}$. The productivity of sugarcane was high in drip irrigation method with $125.86 \mathrm{t} / \mathrm{ha}$ followed by the furrow irrigation method with 110.52 t/ha.

Thus, it could be concluded that the cotton, tapioca, maize and castor were the crops that cultivated under all the three different methods and of which the productivity was high in drip irrigation method for all the crops because of the effective water and other resource management. Cotton productivity in drip irrigation was 19.09 per cent high over the flood irrigation method and 7.09 per cent over the furrow irrigation method. Tapioca production in drip irrigation was 16.67 per cent over the flood irrigation method and 8.15 per cent over the furrow irrigation method. Maize production in drip irrigation was 14.33 per cent and 7.14 per cent over the flood and furrow irrigation methods respectively. Castor production in drip irrigation was 16.94 per cent and 9.02 per cent over the flood and furrow irrigation methods respectively. Thus, the study revealed that productivity in drip 
irrigation method was high as compared to flood and furrow irrigation methods. Narayanamoorthy (2005) reported that the productivity gains due to drip method of irrigation over the flood method of irrigation was about 55 per cent (30 tonnes/acre).

\section{Cost and returns}

The costs and returns for the sample farmers in paddy, cotton and tapioca cultivation respectively in flood, furrow and drip irrigation methods was worked out and the results are given in the table 2 .

It could be observed from the table that the gross income was high for the tapioca cultivation with $₹ 2,45,086$ per ha and it was high over the other crops by 62.83 per cent for the cotton cultivation and 71.14 per cent for the paddy cultivation. Likewise, the net income was also high for the tapioca cultivation with ₹1,51,375 per ha. and it was high over the other crops by 99.27 per cent for the cotton cultivation and 117.37 per cent for the paddy cultivation. The total cost of cultivation was high for the tapioca cultivation with ₹93,711 per ha and it was high over the other crops by 25.70 per cent for cotton cultivation and 27.37 per cent for paddy cultivation. In all the crops, the variable cost occupied the highest proportion to the total cost of cultivation with 62.45 per cent, 67.09 per cent and 58.95 per cent respectively in paddy, cotton and tapioca cultivation. The fixed cost occupied a proportion of 37.55 per cent, 32.91 per cent and 41.05 per cent to the total cost of cultivation respectively in paddy, cotton and tapioca cultivation. Thus, it could be concluded from the table that the tapioca cultivation in drip irrigation method was having the highest gross income and net income followed by the cotton cultivation in furrow irrigation method and the paddy cultivation in flood irrigation method.
Narayanamoorthy (2005) calculated the per acre profit without any discount comes to about Rs. 34.284 and Rs. 13.293 under DMI and FMI respectively. Here, the profit of drip irrigated sugarcane is about Rs. 20.991/acre higher than the flood irrigated sugarcane.

\section{Resource use efficiency}

Cobb-Douglas production was used to estimate the output elasticity with respect to key inputs in the production of crops. The estimated Cobb-Douglas production function for paddy, cotton and tapioca in flood, furrow and drip irrigation methods respectively is furnished in the table 3 .

It could be observed from the table, in paddy production under flood irrigation method, that the dependent variable, that the gross return was responded significantly to the input cost such as seed cost, manures and fertilizers cost, irrigation cost, plant protection cost and machine power cost of the paddy production. The variables of manures and fertilizers cost, irrigation cost and machine power cost were positive and significant at one per cent level with the coefficient values of $0.20,0.45$ and 0.36 respectively, which indicated that an increase in the usage of manures and fertilizers cost, irrigation cost and machine power cost by one per cent from the existing mean level, ceteris paribus would increase the gross return of paddy by 0.20 per cent, 0.45 per cent and 0.36 per cent respectively. Thus, these results indicated that the response was relatively high to the variables of manures and fertilizers cost, irrigation cost and machine power cost because of high significance at one per cent level. The variable namely the plant protection cost was positive and significant at five per cent level with the coefficient value 0.28 , which indicated that an increase in the usage of plant protection chemicals by one per cent from the existing mean level, ceteris paribus would increase the 
gross return of paddy by 0.28 per cent. The variable namely the seed cost was negative and significant at five per cent level with the coefficient value -0.33 , which indicated that the one per cent increase in seed from the existing mean level, ceteris paribus would decrease the gross return of paddy by 0.33 per cent. Ala (2013) showed that the variables of fertilizer, labour and farm size positively influenced yam production.

In furrow irrigation method, that the dependent variable, namely the gross return responded significantly to the input cost such as manures and fertilizers cost, irrigation cost, plant protection cost and human labour cost of the cotton production. The variables of manures and fertilizers cost and human labour cost was positive and significant at one per cent level with the coefficient values 0.29 and 0.42 respectively, which was indicated that an increase in the usage of manures and fertilizers cost and human labour cost by one per cent from the existing mean level, ceteris paribus would increase the gross return of cotton by 0.29 per cent and 0.42 per cent respectively. Thus, these results indicated that the response was relatively high to the manures and fertilizer cost and human labour cost because of high significance at one per cent level. The variable, namely the irrigation cost was positive and significant at five per cent level with the coefficient value 0.27 , which was indicated that an increase in the usage of irrigation cost by one per cent from the existing mean level, ceteris paribus would increase the gross return of cotton by 0.27 per cent. The variable, that the plant protection cost was negative and significant at five per cent level with the coefficient value -0.30 , which indicated that the increase in usage of plant protection cost by one per cent from the existing mean level, ceteris paribus would decrease the gross return of cotton by 0.30 per cent. Thakre et al., (2005) found that the regression coefficients of area, seed and bullock labour were significant. In drip irrigation method, that the dependent variable, namely the gross return responded significantly to the input cost such as manures and fertilizers cost, irrigation cost, plant protection cost and human labour cost of the tapioca production. The variables of manures and fertilizers and irrigation cost was positive and significant at one per cent level with the coefficient values 0.13 and 0.26 respectively, which indicated that an increase in the usage of manures and fertilizers cost and irrigation cost by one per cent from the existing mean level, ceteris paribus would increase the gross return of tapioca by 0.13 per cent and 0.26 per cent respectively. Thus, these results indicated that the response was relatively high to the manures and fertilizer cost and irrigation cost because of high significance at one per cent level. The variables of plant protection cost and the human labour cost was positive and significant at five per cent level with the coefficient values 0.08 and 0.19 respectively, which was indicated that an increase in the usage of plant protection cost and the human labour cost by one per cent from the existing mean level, ceteris paribus, would increase the gross return of tapioca by 0.08 per cent and 0.19 per cent respectively.

\section{Economic efficiency}

The economic efficiency of resource use in paddy, cotton and tapioca production under flood, furrow and drip irrigation method is given in the table 4. In flood irrigation method, it could be seen from the table that the ratio between MVP and MIC of manures and fertilizers cost, irrigation cost and plant protection cost was found to be greater than one, that is MVP is greater than MIC. It indicated that the above resources are at sub optimum level and there exists a possibility for enhancing the gross income of paddy by increasing the respective inputs from the existing level. The reduction in seed cost and 
machine power cost from the existing mean level was required since, the ratio between MVP and MIC is less than one, that is MVP is less than MIC. This shows that currently the seed cost and machine power cost is over utilized in paddy production under the flood irrigation method.

In furrow irrigation method, that the ratio between MVP and MIC of manures and fertilizers cost and irrigation cost was found to be greater than one, that is MVP is greater than MIC. It indicated that the above resources are at sub optimum level and there exists a possibility for enhancing the gross income of paddy by increasing the respective inputs from the existing level. The reduction in plant protection cost and human labour cost from the existing mean level was required since, the ratio between MVP and MIC is less than one, that is MVP is less than MIC. This shows that currently the plant protection cost and human labour cost is over utilized in cotton production under the furrow irrigation method.

In drip irrigation method, that the ratio between MVP and MIC of irrigation cost, plant protection cost and human labour cost was found to be greater than one, that is MVP is greater than MIC. It indicated that the above resources are at sub optimum level and there exists a possibility for enhancing the gross income of paddy by increasing the respective inputs from the existing level. The reduction in manures and fertilizers cost from the existing mean level was required since, the ratio between MVP and MIC is less than one, that is MVP is less than MIC. This shows that currently the manures and fertilizers cost is over utilized in tapioca production under the drip irrigation method. Rupasena et al., (2008) found that to obtain optimum yield levels in rice crop, the farmer must reduce the expenditure on fertilizer and labour and should increase the seed rate.

\section{Technical efficiency}

Data Envelopment Analysis was attempted to measure the technical efficiency of paddy, cotton and tapioca in flood, furrow and drip irrigation methods respectively. The Data Envelopment Analysis (DEA) is a nonparametric mathematical programming methodology based on the works of Farrell (1957) and Fraser and Cordina (1999).

The results of technical efficiency and scale efficiency of paddy, cotton and tapioca in flood, furrow and drip irrigation methods respectively is furnished in the table 5. It could be observed from the table that the variation in the levels of technical efficiency of paddy ranged from 85.00 to 100.00 with mean efficiency of 95.00 per cent. The mean level of technical efficiency indicates that on an average five per cent of paddy farmers falling short of the maximum possible level of technology. Therefore, it was possible to increase the paddy yield by 5.00 per cent of the paddy farmers on average by adopting the technology used by best performers.

The variation in the levels of technical efficiency of cotton was ranged from 79.00to 100.00 with mean efficiency of 90.00 per cent. The mean level of technical efficiency indicates that on an average 10.00 per cent of cotton farmers falling short of the maximum possible level of technology. Therefore, it was possible to increase the cotton yield by 10.00 per cent of the cotton farmers on average by adopting the technology used by best performers. Likewise, the variation in the levels of technical efficiency of tapioca was ranged from 83.00 to 100.00 with mean efficiency of 91.00 per cent (Table 6). 
Table.1 Average productivity of major crops (in tonnes/ha)

\begin{tabular}{|c|c|c|c|c|}
\hline S. No. & Crop & Flood & Furrow & Drip \\
\hline $\mathbf{1 .}$ & Paddy & 6.70 & - & - \\
\hline $\mathbf{2 .}$ & Cotton & 2.41 & 2.68 & 2.87 \\
\hline $\mathbf{3 .}$ & Tapioca & 33.00 & 35.60 & 38.50 \\
\hline $\mathbf{4 .}$ & Maize & 3.28 & 3.50 & 3.75 \\
\hline $\mathbf{5 .}$ & Sorghum & 2.50 & 3.10 & - \\
\hline $\mathbf{6 .}$ & Castor & 1.24 & 1.33 & 1.45 \\
\hline $\mathbf{7 .}$ & Groundnut & 2.60 & - & 2.71 \\
\hline $\mathbf{8 .}$ & Sugarcane & - & 110.52 & 125.86 \\
\hline
\end{tabular}

Table. 2 Costs and returns in paddy, cotton and tapioca cultivation (in ₹/ha)

\begin{tabular}{|c|c|c|c|c|}
\hline S. No. & Particulars & Paddy & Cotton & Tapioca \\
\hline $\mathbf{1 .}$ & Fixed cost & 27,625 & 24,536 & 38,468 \\
\hline & & $(37.55)$ & $(32.91)$ & $(41.05)$ \\
\hline 2. & Variable cost & 45,947 & 50,018 & 55,243 \\
& & $(62.45)$ & $(67.09)$ & $(58.95)$ \\
\hline 3. & Total cost of cultivation & 73,572 & 74,554 & 93,711 \\
& & $(100.00)$ & $(100.00)$ & $(100.00)$ \\
\hline 4. & Gross income & $1,43,210$ & $1,50,520$ & $2,45,086$ \\
\hline & Net income & 69,638 & 75,966 & $1,51,375$ \\
\hline
\end{tabular}

(*Figures in parenthesis indicate percentage to total)

Table.3 Resource use efficiency in paddy, cotton and tapioca production

\begin{tabular}{|c|l|c|c|c|}
\hline S. No. & \multicolumn{3}{|c|}{ Variables } & \multicolumn{3}{|c|}{ Regression coefficient } \\
\cline { 3 - 5 } & & Paddy & Cotton & Tapioca \\
\hline 1. & Regression Constant & $2.65^{\mathrm{NS}}$ & $1.83^{* *}$ & $-2.07^{\mathrm{NS}}$ \\
\hline 2. & Seed cost (Rs/ha) & $-0.33^{*}$ & $-0.21^{\mathrm{NS}}$ & $0.52^{\mathrm{NS}}$ \\
\hline 3. & Manures and fertilizers cost (Rs/ha) & $0.20^{* *}$ & $0.29^{* *}$ & $0.13^{* *}$ \\
\hline $\mathbf{4 .}$ & Irrigation cost (Rs/ha) & $0.45^{* *}$ & $0.27^{*}$ & $0.26^{* *}$ \\
\hline $\mathbf{5 .}$ & Plant protection cost (Rs/ha) & $0.28^{*}$ & $-0.30^{*}$ & $0.08^{*}$ \\
\hline 6. & Human labour cost (Rs/ha) & $0.12^{\mathrm{NS}}$ & $0.42^{* *}$ & $0.19^{*}$ \\
\hline $\mathbf{7 .}$ & Machine power cost $(\mathrm{Rs} / \mathrm{ha})$ & $0.36^{* *}$ & $0.55^{\mathrm{NS}}$ & $-0.45^{\mathrm{NS}}$ \\
\hline $\mathbf{9 .}$ & $\overline{\mathrm{R}}^{2}$ (Adjusted $\mathrm{R}^{2)}$ & 0.79 & 0.87 & 0.80 \\
\hline
\end{tabular}

$\mathrm{N}=60$, ** Significant at 1 percent level, ${ }^{*}$ Significant at 5 percent level, NS- Non significant 
Table.4 Economic efficiency of resource use in paddy, cotton and tapioca production

\begin{tabular}{|c|l|c|c|c|}
\hline \multirow{2}{*}{ S. No. } & \multicolumn{1}{|c|}{ Variables } & \multicolumn{3}{|c|}{ MVP / MIC } \\
\cline { 3 - 5 } & & Paddy & Cotton & Tapioca \\
\hline 1. & Seed cost (Rs/ha) & -14.33 & - & - \\
\hline 2. & Manures and fertilizers cost (Rs/ha) & 1.50 & 1.14 & 0.93 \\
\hline 3. & Irrigation cost (Rs/ha) & 5.69 & 2.35 & 15.25 \\
\hline 4. & Plant protection cost (Rs/ha) & 4.73 & -0.96 & 3.86 \\
\hline 5. & Human labour cost (Rs/ha) & - & 0.80 & 2.96 \\
\hline 6. & Machine power cost (Rs/ha) & 0.88 & - & - \\
\hline
\end{tabular}

Table.5 Technical efficiency and scale efficiency of paddy, cotton and tapioca cultivation

\begin{tabular}{|c|l|c|c|c|c|c|c|}
\hline \multirow{2}{*}{ S. No. } & \multirow{2}{*}{ Parameters } & \multicolumn{3}{|c|}{ Technical efficiency } & \multicolumn{3}{c|}{ Scale efficiency } \\
\cline { 3 - 8 } & & Paddy & Cotton & Tapioca & Paddy & Cotton & Tapioca \\
\hline 1. & Mean & 0.95 & 0.90 & 0.91 & 0.92 & 0.96 & 0.93 \\
\hline 2. & $\begin{array}{l}\text { Standard } \\
\text { deviation }\end{array}$ & 0.03 & 0.08 & 0.05 & 0.06 & 0.03 & 0.05 \\
\hline 3. & Minimum & 0.85 & 0.79 & 0.83 & 0.89 & 0.81 & 0.86 \\
\hline 4. & Maximum & 1.00 & 1.00 & 1.00 & 1.00 & 1.00 & 1.00 \\
\hline
\end{tabular}

Table.6 Frequency distribution of paddy, cotton and tapioca cultivation on technical efficiency and scale efficiency

\begin{tabular}{|c|c|c|c|c|c|c|c|}
\hline S. & \multirow{2}{*}{ No. } & Frequency & \multicolumn{3}{|c|}{ Technical efficiency } & \multicolumn{3}{|c|}{ Scale efficiency } \\
\cline { 3 - 8 } & levels & Paddy & Cotton & Tapioca & Paddy & Cotton & Tapioca \\
\hline 1. & $<95$ & 33 & 27 & 31 & 29 & 25 & 30 \\
& & $(55.00)$ & $(45.00)$ & $(51.67)$ & $(48.33)$ & $(41.66)$ & $(50.00)$ \\
\hline 2. & $96-98$ & 8 & 11 & 9 & 7 & $9(15.00)$ & 12 \\
& & $(13.33)$ & $(18.33)$ & $(15.00)$ & $(11.67)$ & & $(20.00)$ \\
\hline 3. & $>98$ & 29 & 32 & 20 & 24 & 26 & 18 \\
& & $(48.33)$ & $(53.33)$ & $(33.33)$ & $(40.00)$ & $(43.33)$ & $(30.00)$ \\
\hline 4. & Total & 60 & 60 & 60 & 60 & 60 & 60 \\
& & $(100.00)$ & $(100.00)$ & $(100.00)$ & $(100.00)$ & $(100.00)$ & $(100.00)$ \\
\hline
\end{tabular}

(*Figures in parenthesis indicate percentage to total) 
Table.7 Risk management strategies followed by the farmers under flood, furrow and drip irrigation methods

\begin{tabular}{|c|c|c|c|c|c|c|c|}
\hline \multirow[t]{2}{*}{ S. No. } & \multirow{2}{*}{$\begin{array}{c}\text { Risk management } \\
\text { strategy }\end{array}$} & \multicolumn{2}{|c|}{ Flood } & \multicolumn{2}{|c|}{ Furrow } & \multicolumn{2}{|c|}{ Drip } \\
\hline & & $\begin{array}{l}\text { No. of } \\
\text { farmers }\end{array}$ & Rank & $\begin{array}{l}\text { No. of } \\
\text { farmers }\end{array}$ & Rank & $\begin{array}{l}\text { No. of } \\
\text { farmers }\end{array}$ & Rank \\
\hline 1. & Inter cropping & $\begin{array}{c}20 \\
(33.33)\end{array}$ & IV & $\begin{array}{c}25 \\
(41.67)\end{array}$ & IV & $\begin{array}{c}3 \\
(5.00)\end{array}$ & VII \\
\hline 2. & Crop insurance & $\begin{array}{c}12 \\
(20.00)\end{array}$ & VII & $\begin{array}{c}30 \\
(50.00)\end{array}$ & III & $\begin{array}{c}17 \\
(28.33)\end{array}$ & IV \\
\hline 3. & Crop diversification & $\begin{array}{c}33 \\
(55.00)\end{array}$ & III & $\begin{array}{c}18 \\
(30.00)\end{array}$ & $\mathrm{V}$ & $\begin{array}{c}31 \\
(51.67)\end{array}$ & II \\
\hline 4. & Varietal diversification & $\begin{array}{c}15 \\
(25.00)\end{array}$ & VI & $\begin{array}{c}12 \\
(20.00)\end{array}$ & VI & $\begin{array}{c}22 \\
(36.67)\end{array}$ & III \\
\hline 5. & $\begin{array}{l}\text { Soil conservation and land } \\
\text { management practices }\end{array}$ & $\begin{array}{c}44 \\
(\mathbf{7 3 . 3 3})\end{array}$ & I & $\begin{array}{c}45 \\
\mathbf{( 7 5 . 0 0 )}\end{array}$ & $\mathbf{I}$ & $\begin{array}{c}10 \\
(16.67)\end{array}$ & V \\
\hline 6. & $\begin{array}{l}\text { Effective irrigation } \\
\text { management practices }\end{array}$ & $\begin{array}{c}38 \\
(63.33)\end{array}$ & II & $\begin{array}{c}37 \\
(61.67)\end{array}$ & II & $\begin{array}{c}35 \\
(58.33)\end{array}$ & I \\
\hline 7. & Construction of farm pond & $\begin{array}{c}17 \\
(28.33)\end{array}$ & V & $\begin{array}{c}5 \\
(8.33)\end{array}$ & VII & $\begin{array}{c}8 \\
(13.33)\end{array}$ & VI \\
\hline
\end{tabular}

(*Figures in parenthesis indicate percentage to total)

The mean level of technical efficiency indicates that on an average 9.00 per cent of tapioca farmers falling short of the maximum possible level of technology. Therefore, it was possible to increase the tapioca yield by 9.00 per cent of the tapioca farmers on average by adopting the technology used by best performers. Similarly, the high average technical efficiency was reported by Saranya (2013) who showed that the mean technical efficiency score of sugarcane and groundnut was 94.00 per cent and 95.00 per cent respectively in Namakkal district.

The scale efficiency of paddy ranged from 89.00 to 100.00 per cent with mean scale efficiency of 92.00 per cent, the scale efficiency of cotton was ranged from 81.00 to 100.00 percent with mean scale efficiency of 96.00 per cent and the scale efficiency of tapioca ranged from 86.00 to 100.00 percent with mean scale efficiency of 93.00 per cent. Thus, the results indicated that all the paddy, cotton and tapioca crops in their respective irrigation methods operating at optimal size since the mean scale efficiency is more than 90 per cent for all the three crops and among the three crops, cotton had a higher scale efficiency of 96 per cent than others. Similarly, the high average scale efficiency was reported by Saranya (2013) who showed that the mean scale efficiency of 94.00 per cent and 97.00 per cent for sugarcane and groundnut respectively in Namakkal district. Nasurudeen (2009) projected the technical, allocative and scale efficiency of paddy farms using DEA. The result concluded that mean technical efficiency, mean allocative efficiency and mean scale efficiency was 64 , 76 and 94 per cent respectively.

\section{Risk management strategies}

The major risks present in the study area were effectively managed by adopting the various risk management strategies by farmers under the three different irrigation methods. The main strategies are intercropping, crop 
insurance, crop diversification, varietal diversification, soil conservation and land management practices, effective irrigation management practices and construction of farm pond in their own field for water saving and conservation for future use. These all are the strategies adopted by the farmers with different proportions based on the type of risk and irrigation methods.

Risk management strategies followed by the farmers under flood, furrow and drip irrigation method are presented in the table 7 . In flood irrigation method, it could be observed from the table that soil conservation and land management practices were the major adopted strategy which was ranked first with a proportion of 73.33 per cent of farmers. Soil erosion, runoff water, heavy flooding and unequal distribution of water during the irrigation were the major risks by the flood irrigated farmers. So, the majority of flood irrigated farmers have adopted the soil conservation and land management practices which were land levelling, earthing up, mulching and zero tillage. The effective irrigation management practices ranked second with a proportion of 63.33 per cent which was reducing the number and time of irrigation to reduce the irrigation water requirement based on water availability. The crop diversification ranked third with a proportion of 55.00 per cent farmers with raising of other crops like groundnut, cotton, maize and vegetables along with paddy. Inter cropping ranked fourth with a proportion of 33.33 per cent, where pulses (red gram, black gram, Bengal gram), castor and vegetables like onion, and chilli were adopted by most of the flood irrigated farmers for managing the risk of main crop failure and also for additional income. Construction of farm ponds ranked fifth with 28.33 per cent of farmers for saving the run off rain water for future use in water scarcity period. The varietal diversification ranked sixth with
25.00 per cent of farmers were going to high yielding varieties like IR-50 and Andhraponni of paddy instead of long duration variety (white ponni) for managing the production risks. The least adopted strategy was crop insurance which ranked seventh with a proportion of 20.00 per cent of farmers. Raghavendra and Suresh (2018) revealed that the major risks were related to untimely rainfall, drought and biotic factors like diseases and pest. The major adaptation strategies adopted were intercropping (49\%), crop insurance $(45 \%)$, micro irrigation $(17 \%)$ and varietal diversification (39\%).

In furrow irrigation method, it could be observed from the table 7 that soil conservation and land management practices were the major adopted strategy which was ranked first with 75.00 per cent of farmers followed by effective irrigation management practices ranked second with 61.67 per cent which were almost same as in the flood irrigation method. Crop insurance ranked third with 50.00 per cent of farmers. Inter cropping ranked fourth with 41.67 per cent of farmers, where turmeric, vegetables and pulses were intercropped by the furrow irrigated farmers. Crop diversification ranked fifth with 30.00 per cent of farmers as farmers were going for other crops like sorghum, maize, and vegetables instead of cotton. The varietal diversification ranked sixth with 20.00 per cent of farmers, as farmers were raising Bt-cotton varieties instead of the normal traditional varieties of cotton for managing the yield and pest risk. The least adoption strategy was construction of farm ponds which ranked with a proportion of 8.33 per cent of farmers. Salazar and Rand (2016) reported that the credit access, extension services and production variance were the most important risk. This increased risk may be because of lack of diffusion and knowledge on water-saving technology of the farmers. 
In drip irrigation method, it could be observed from the table 7 that effective irrigation management practices were the major adopted strategy which was ranked first with 58.33 per cent of farmers. The drip irrigated farmers were using the irrigation water effectively which increases the water use efficiency of crops and also reduce the irrigation water requirement. This was followed by the crop diversification which ranked second with 51.67 per cent of farmers were going for other crops like cotton, caster, maize and vegetables (Brinjal, chilli) along with tapioca. The varietal diversification ranked third with 36.67 per cent of farmers as they adopt short duration, high yielding and drought tolerance varieties of tapioca. The crop insurance ranked fourth with 28.33 per cent of farmers. The soil conservation and land management practices ranked sixth with 16.67 per cent of famers. The least adopted strategy was intercropping which ranked seventh only with 5.00 per cent of farmers. Torkamani and Shajari (2007) demonstrated that the farmers that are more risk-averse with respect to use of water are more likely to adopt new irrigation technologies that allowed them to save water and decreased their production (yield) risk

In conclusions and Policy implications the results indicated that the productivity and net income was high in drip irrigation method followed by furrow and flood irrigation method respectively since in drip irrigation, effective water management occurs during the water scarcity period. So, flood and furrow irrigated farmers should be motivated to adopt the drip irrigation method for water saving and also to attain higher net return. Resource use and economic efficiency concluded that in all the three irrigation methods, irrigation had a significant influence on the gross return of crops especially with respect to paddy and tapioca. Also, in all the three irrigation methods, the irrigation resource was used at sub-optimal level and hence there exists a possibility for increased utilization of this resource to raise the productivity of respective crops. So, farmers should be motivated to go for optimal irrigation especially with drip irrigation. In the flood irrigation method, seed cost was found as over utilized input for paddy cultivation and in furrow irrigation method, plant protection cost was overutilized resource for cotton cultivation. Hence, Agricultural Extension Department should conduct training programme on the effective usage of inputs for reduce the cost of cultivation and increase the output of crop. Among the risk management strategies, the soil conservation and land management practices were ranked first in both the flood and furrow irrigation methods and the effective irrigation management practices were ranked first in drip irrigation methods. Also, the extension department create awareness to all the level of farmers by conducting farmers meetings and through training programmes in village level.

\section{References}

Ala A. L., 2013. "Determination of profitability and resource use efficiency of yam production by women in Bosso local government area of Niger State, Nigeria." European Scientific journal, ESJ, 9(16).

Amarnath J. S., Saranya S., 2014. "An economic analysis of sustainability in Namakkal district of Tamil Nadu."Wyno Academic Journal of Agricultural Sciences, 2(1): 1-18.

Basavaraja H., Mahajanashetti S.B., and Sivanagaraju P., 2008. "Technological Change in Paddy Production: A Comparative Analysis of Traditional and SRI Systems of Cultivation", Indian Journal of Agricultural Economics, Vol. 63, No. 4.

Narayanamoorthy A., 2005. "Economics of 
Drip Irrigation in Sugarcane Cultivation: Case Study of a Farmer from Tamil Nadu, Indian Journal of Agricultural Economics, Vol. 60, No. 2.

Nasurudeen P., 2009. Efficiency of Rice Production in Union Territory of Pondicherry, Agricultural Economics Research Review, 22: pp.361-364.

Raghavendra K. J. and Suresh A., 2018. Risk management in rainfed agriculture: An analysis of strategies and adaptations followed by farmers in Madhya Pradesh. Indian Journal of Agricultural Sciences, 88 (6): 895-901.

Rupasena, L.P., Vijayakumar H.S. and Kerur N.M., 2008. Resource Use Efficiency in Rice Cultivation in Sri Lanka, Indian
Journal of Agricultural Marketing, 22(2): 1-11.

Salazar C. and Rand J., 2016. "Production risk and adoption of irrigation technology: evidence from small-scale farmers in Chile". Latin American Economic Review, 25:2, DOI 10.1007/s40503-016-0032-3.

Thakare A.B., Pajankar, V.D. and PajankarS., 2005. "Resource productivity and Resource efficiency of Turmeric", Rural India, 68(4): 73-76.

Torkamani J., Shajari S., 2008. Adoption of New Irrigation Technology Under Production Risk. Water Resource Management, 22:229-237.

\section{How to cite this article:}

Jayapradha, K., J. S. Amarnath and Sivasankari, B. 2020. An Economic Analysis of Resource Use Efficiency, Technical Efficiency and Risk Management Strategies under Different Irrigation Methods in Tamil Nadu, India. Int.J.Curr.Microbiol.App.Sci. 9(11): 703-714. doi: https://doi.org/10.20546/ijcmas.2020.911.085 